This article is licensed under the Creative Commons Attribution-NonCommercial 4.0 International License (CC BY-NC) (http://www.karger.com/Services/OpenAccessLicense). Usage and distribution for commercial purposes requires written permission.

\title{
CDC Group EO-4 and Candida tropicalis Peritonitis in a Patient on Peritoneal Dialysis after Upper Endoscopy, Colonoscopy and Coil Embolization of the Gastroduodenal Artery
}

\author{
Shameek Gayen Yonah Ziemba Shikha Jaiswal Adam Frank \\ Yasmin Brahmbhatt \\ Thomas Jefferson University, Philadelphia, PA, USA
}

\section{Keywords}

Candida tropicalis peritonitis · Peritoneal dialysis · Fungal peritonitis · CDC group EO-4 organism peritonitis

\begin{abstract}
Peritoneal dialysis (PD) is an excellent form of renal replacement therapy for many patients with end-stage renal disease (ESRD). Over 10,000 patients receive PD in the United States [United States Renal Data System: 2015 USRDS Annual Data Report: Epidemiology of Kidney Disease in the United States, 2015]. PD has superior outcomes compared to hemodialysis in the first 2 years of ESRD [Sinnakirouchenan and Holley: Adv Chronic Kidney Dis 2011;18:428 432]. However, peritonitis is a known complication and may result in significant morbidity and necessitate transition to hemodialysis, which increases medical costs [Holley and Piraino: Semin Dial 1990;3:245-248]. We report the first case of a PD patient who underwent endos-
\end{abstract}




\section{Case Reports in Gastroenterology}

Case Rep Gastroenterol 2016;10:728-732

(c) 2016 The Author(s). Published by S. Karger AG, Basel www.karger.com/crg

Gayen et al.: CDC Group EO-4 and C. tropicalis Peritonitis in a Patient on PD after Upper Endoscopy, Colonoscopy and Coil Embolization of the Gastroduodenal Artery

copy, colonoscopy and CT angiogram with coil embolization for gastrointestinal bleeding without antibiotic prophylaxis and subsequently developed CDC group EO-4 organism and fungal peritonitis.

(C) 2016 The Author(s)

Published by S. Karger AG, Basel

\section{Introduction}

Peritonitis is a serious and common complication of peritoneal dialysis (PD). Although only $5 \%$ of peritonitis episodes result in death, peritonitis is the direct or major contributing cause of death in around 16\% of PD patients. Severe or prolonged peritonitis can also lead to structural and functional alterations of the peritoneal membrane, eventually leading to membrane failure which subsequently leads to transition to hemodialysis. This case confirms the need for prophylactic antibiotics prior to invasive gastrointestinal procedures to prevent peritonitis.

\section{Case Report}

A 57-year-old female with rectal cancer successfully treated with chemotherapy and radiation over a year ago, renal cell cancer with subsequent nephrectomy and ESRD from lupus nephritis, and on PD since 2014 presented to an outside hospital with melena. She underwent colonoscopy and endoscopy that revealed a clean-based duodenal ulcer that was treated with twice daily intravenous pantoprazole. Several days later, she presented with another gastrointestinal bleed requiring repeat upper endoscopy and subsequently angiogram and coil embolization of the gastroduodenal artery. PD treatments were withheld and she received hemodialysis treatments via her arteriovenous fistula during this hospitalization. She had not received prophylactic antibiotics to prevent peritonitis prior to these procedures. In the interim, she was diagnosed with Clostridium difficile diarrhea, which was treated with oral vancomycin.

Following her second endoscopy, she developed diffuse abdominal pain and became febrile to $100.6^{\circ} \mathrm{F}$. Her abdomen was soft but diffusely tender. Peritonitis was suspected and her peritoneal fluid effluent was drawn for analysis (Table 1). Gram stain of the peritoneal fluid revealed gram-positive cocci, and cultures grew gram-positive micrococcus and Candida tropicalis. Intravenous vancomycin and oral fluconazole were initiated. Final culture growth revealed the CDC group EO-4 organism, which was susceptible to levofloxacin. She was switched to levofloxacin to complete a total of 2 weeks of antibiotics. She was discharged home on PD and was readmitted 1 day later for hematochezia. She continued to have abdominal cramps unchanged in severity from before, but bleeding scan followed by a third endoscopy remained negative.

She was then transferred to our institution for further evaluation and consideration for double-balloon enteroscopy. Upon arrival, her vital signs were stable: blood pressure $122 / 75 \mathrm{~mm} \mathrm{Hg}$, heart rate 85 , temperature $97.6^{\circ} \mathrm{F}$. Cardiac examination was benign and lungs were clear to auscultation. Her abdominal examination revealed an intact PD catheter exit site without erythema or exudate, a diffusely tender abdomen without rebound or 


\section{Case Reports in \\ Gastroenterology}

Case Rep Gastroenterol 2016;10:728-732

(c) 2016 The Author(s). Published by S. Karger AG, Base www.karger.com/crg

Gayen et al.: CDC Group EO-4 and C. tropicalis Peritonitis in a Patient on PD after Upper Endoscopy, Colonoscopy and Coil Embolization of the Gastroduodenal Artery

guarding, no lower extremity edema, and the left upper extremity revealed a brachiocephalic arteriovenous fistula with bruit. Laboratory values were as follows: hemoglobin $10.8 \mathrm{~g} / \mathrm{dL}$, white blood cell count $4.2 \times 10^{9} / \mathrm{L}$, platelet count $110 \times 10^{9} / \mathrm{L}$, normal transaminases, alkaline phosphatase $245 \mathrm{IU} / \mathrm{L}$, total bilirubin $0.3 \mathrm{mg} / \mathrm{dL}$, serum albumin $1.3 \mathrm{~g} / \mathrm{dL}$, and serum lactate level $0.8 \mathrm{mmol} / \mathrm{L}$. Serum coagulation studies were normal. Serum electrolytes revealed a bicarbonate level of $25 \mathrm{mmol} / \mathrm{L}$, potassium $3.4 \mathrm{mmol} / \mathrm{L}$, BUN $15 \mathrm{mg} / \mathrm{dL}$, and creatinine $6.9 \mathrm{mg} / \mathrm{dL}$. Urinalysis was benign with only 4 white cells/HPF and negative leukocyte esterase and nitrite. Clostridium difficile toxin was negative. Serum lipase was normal at $6 \mathrm{U} / \mathrm{L}$. Peritoneal fluid cell count and culture was repeated at our institution (Table 1). Abdominal CT with oral and intravenous contrast revealed wall thickening in the right colon extending to the proximal portion of the transverse colon compatible with regional colitis. There was a moderate amount of ascites related to PD. The PD catheter entered the right lower quadrant and coiled in the right lower quadrant. There was an abdominal wall fluid collection around the insertion of the PD catheter. Capsule endoscopy was unrevealing.

Given multiple gastrointestinal procedures, recent $C$. difficile infection which had been adequately treated, and incomplete treatment for a recent fungal peritonitis, her persistent abdominal pain was attributed to intractable catheter-related fungal peritonitis. Surgical catheter removal was performed and she was switched to hemodialysis. Catheter tip culture grew $C$. tropicalis. The fungal peritonitis was treated with oral fluconazole for 2 months. Her abdominal pain improved and she was discharged home.

\section{Discussion}

In PD patients, peritonitis is diagnosed by abdominal pain, a cloudy dialysate effluent, and a peritoneal fluid white blood cell count greater than $100 / \mu \mathrm{L}$ and/or at least $50 \%$ neutrophils [1]. Peritonitis may arise from transmural migration of bacteria from the bowel to the peritoneal cavity after manipulation of the gastrointestinal tract [2]. Several reports have described the development of peritonitis in PD patients who underwent GI endoscopy without prophylaxis [3-6], and a retrospective study found that the risk of peritonitis after colonoscopy without antibiotic prophylaxis was 6.3\% [7]. Peritoneal fluid in these patients has yielded gram-positive and gram-negative organisms [2, 8]. The CDC group EO-3 organism has been reported to cause peritonitis in a PD patient [9]. However, this is the first report of a CDC group E0-4 organism causing peritonitis. It is an aerobic gram-negative organism which has been isolated from blood, urine, and nasal secretions [10].

Our patient developed fungal peritonitis, which is an indication for transition from PD to hemodialysis for at least 6 months. To reduce the risk of peritonitis in PD patients, the International Society of Peritoneal Dialysis recommends intravenous $1 \mathrm{~g}$ ampicillin plus one dose of aminoglycoside with or without metronidazole and emptying the abdomen of fluid before endoscopic procedures [11]. The American Society of Gastrointestinal Endoscopy suggests prophylactic antibiotics before colonoscopy [12]. Gastroenterologists, infectious disease specialists and nephrologists need to be aware of the risks of gastrointestinal procedures in PD patients without administering antibiotic prophylaxis. 


\section{Conclusion}

Gastrointestinal procedures without antibiotic prophylaxis in PD patients can lead to peritonitis, which leads to significant morbidity. Further randomized multicenter studies are needed in PD patients to determine prophylactic antibiotic class and efficacy.

\section{Statement of Ethics}

Informed consent was obtained from the patient for publication of their information for this case report.

\section{Disclosure Statement}

The authors have nothing to disclose.

\section{References}

1 Li PK, Szeto CC, Piraino B, et al: Peritoneal dialysis-related infections recommendations: 2010 update. Perit Dial Int 2010;30:393-423.

2 Gould AL, Chahla E, Hachemb C: Peritonitis following endoscopy in a patient on peritoneal dialysis with a discussion of current recommendations on antibiotic prophylaxis. Case Rep Gastroenterol 2015;9:302-306.

3 Bac DJ, et al: Peritonitis following endoscopic polypectomy in a peritoneal dialysis patient: the need for antibiotic prophylaxis. Infection 1994;22:220-221.

$4 \quad$ Holley J, et al: Peritonitis following colonoscopy and polypectomy: a need for prophylaxis. Perit Dial Bull 1987;7:105.

5 Verger C, et al: Colonoscopy and continuous ambulatory peritoneal dialysis. Gastrointest Endosc 1987;33:334-335.

6 Sprenger R, et al: Enterococcus-peritonitis after endoscopic polypectomy: need for prophylactic antibiotics. Perit Dial Bull 1987;7:263.

7 Yip T, Tse K, Lam M, et al: Risks and outcomes of peritonitis after flexible colonoscopy in CAPD patients. Perit Dial Int 2007;27:560-564.

8 Machuca E, Ortiz A, Rabagliati R: Streptococcus viridans-associated peritonitis after gastroscopy. Adv Perit Dial 2005;21:60-62.

-9 Daley D, Neville S, Kociuba K: Peritonitis associated with a CDC group EO-3 organism. J Clin Microbiol 1997;35:3338-3339.

10 Berger S: CDC group EO-4; in Gideon Informatics Inc (ed): GIDEON Guide to Medically Important Bacteria (e-book). Los Angeles, Gideon Informatics, 2015.

11 Piraino B, Bernardini J, Brown E, et al: ISPD position statement on reducing the risks of peritoneal dialysis-related infections. Perit Dial Int 2011;31:614-630.

12 Khashab MA, Chithadi KV, Acosta RD, et al: Antibiotic prophylaxis for GI endoscopy. Gastrointest Endosc 2015;81:81-89. 
The data reported here have been supplied by the United States Renal Data System (USRDS). The interpretation and reporting of these data are the responsibility of the author(s) and in no way should be seen as an official policy or interpretation of the US government.

Table 1. Peritoneal fluid analysis

\begin{tabular}{|c|c|c|c|c|c|}
\hline $\begin{array}{l}\text { Days since admis- } \\
\text { sion }\end{array}$ & $\begin{array}{l}\text { - Fluid appear- } \\
\text { ance }\end{array}$ & $\begin{array}{l}\text { Fluid red cell } \\
\text { count }\end{array}$ & $\begin{array}{l}\text { Fluid white cell } \\
\text { count }\end{array}$ & $\begin{array}{l}\text { Fluid neutro- } \\
\text { phils }\end{array}$ & Organism \\
\hline 7 & Cloudy & $<3,000$ & 97 & $95 \%$ & $\begin{array}{l}\text { Gram-positive micro- } \\
\text { coccus, } C \text {. tropicalis, } \\
\text { CDC group EO-4 }\end{array}$ \\
\hline 20 & Clear & 0 & 67 & $75 \%$ & C. tropicalis \\
\hline
\end{tabular}

